\title{
Hälsoprofessioner: Teoretiska perspektiv och forskningstrender
}

\author{
ELIANNE RISKA
}

\begin{abstract}
Professionsforskningen kännetecknas av olika teoretiska tolkningar. Denna artikel ger en översikt av de mest framträdande teoretiska tolkningarna om hälsoprofessionernas ställning och arbete. Den ger dessutom ett genusperspektiv på hälsoprofessioner och en vision om framtida forskning under globalisering.
\end{abstract}

\section{Inledning}

Sociologins historia är en berättelse om samhällets modernisering och utveckling och i denna berättelse har de kunskapsbaserade yrkena använts som illustration för hur några av dem har en strategisk ställning i samhällsförändringen. Detta sociologiska gebit går under benämningen professionssociologi. Syftet med denna artikel är att sammanfatta de centrala teoretiska frågorna i den professionssociologiska diskussionen och traditionen. I denna har läkarprofessionen använts som ett modell-

Elianne Riska, professor i sociologi vid Svenska social- och kommunalhögskolan, Helsingfors universitet. exempel på en modern profession och dess roll. Den första delen av artikeln redogör för det funktionalistiska, interaktionistiska och nyweberianska perspektivet samt systemteorin och det poststrukturalistiska perspektivet på läkarprofessionens särställning i jämförelse med andra hälsoprofessioner. I nyare arbeten har de ledande teoretiska perspektiven kritiserats för att de har varit könsneutrala och för att de har lämnat obeaktade de egenskaper som kvinnor tillför hälsovården. Den andra delen av artikeln presenterar därför genusperspektivet på frågan om orsaken till yrkesgruppers över- och underordning i hälsovården. Den avslutande delen lyfter fram de teoretiska utmaningar som studier om hälsoprofessioner står inför då globaliseringen raderar de 
nationella gränser som utgjort kontexten för de traditionella professionsstudierna.

\section{Teoretiska tolkningar om läkarens roll i den moderna hälsovården}

Professionssociologin fick sin början i de stora samhälleliga frågorna som sociologin tog sig an då den var en ny vetenskap. Sociologins klassiker gav de teoretiska referensramarna för den moderna professionssociologin. Max Weber tolkade moderniseringsprocessen i termerna ökad byråkratisering och rationalitet medan Emile Durkheim betonade de professionella organisationernas roll som en länk mellan individen, marknaden och staten. Den amerikanska sociologen Talcott Parsons ambition var att skapa en modern sociologi — "en teori om socialt handlande" - som integrerade dessa centrala tankegångar i sociologins klassiker. I boken "The Social System", specifikt i dess tionde kapitel, lanserade Parsons (1951) en teori om läkar-patientrelationen som ett exempel på den typ av nya kontraktsrelationer baserade på tillit som hade uppstått i det moderna samhället. Parsons såg läkarprofessionen som en prototyp för de värderingar och beteenden som karakteriserade en modern profession.

Parsons teori kan karakteriseras som normativ och funktionalistisk. Normerna för professionellt beteende - neutralitet, specifikhet, universalism, kollektiv orientering, uppnådd status — skiljde professioner från andra yrkesgrupper. Institutionaliseringen av professionernas särställning i arbetslivet ansågs vara baserad på den vik- tiga funktion som de utförde i säkrandet av individens och samhällets välfärd.

Parsons tolkning av professionernas roll och hans allmänna sociologiska teori kom att prägla huvudfåran av allmän sociologi och professionssociologi under 1950- och 1960-talet. Den tidiga forskningen strävade efter att finna de egenskaper som karakteriserade de yrkesgrupper som nått en särställning som profession. Denna deskriptiva ansats har kallats den egenskapsorienterade ansatsen (traits approach) (Evetts m.fl. 2009: 142). En annan del av den tidiga empiriska forskningen strävade efter att identifiera de kulturella och strukturella processer som präglar den socialisationsprocess som garanterar att professionens nya medlemmar omfattar de värderingar och beteenden som förväntas av yrkeskårens medlemmar. Klassiker på det här området är två studier om den amerikanska läkarutbildningen som gjordes i slutet av 1950-talet: den så kallade Chicagoskolans studie "Boys in White" utförd av Howard Becker och hans medarbetare (Becker m.fl. 1961) och den så kallade Columbia universitetets studie utförd av Robert Merton och hans medarbetare (Merton m.fl. 1957).

Ett paradigmskifte skedde i början på 1970-talet då den amerikanska sociologen Eliot Freidson i boken "Profession of Medicine" (1970) lanserade ett konfliktperspektiv på läkarprofessionens makt. Enligt Freidson baserades läkarkårens professionella dominans inte på dess kunskap i sig utan på dess monopol på kunskap, som den hade tillskansat sig genom att övertyga makthavarna om nödvändigheten i att kringgärda ett specifikt mandat för ensamrätt till gruppens verksamhet. Genom att 
betona sin specifika kunskap och yrkeskod som garant för professionellt arbete hade läkarkåren uppnått professionell dominans, som samtidigt underordnade andra yrkesgrupper i hälsovården. Freidsons modell har också gått under benämningen monopolperspektivet.

Freidsons ursprungliga modell byggde på hans mentors, Everett Hughes, syn på arbetets karaktär. Hughes samling av essäer, som utkom under benämningen "Men and their Work" (1958), byggde på uppfattningen att det inte existerade någon skillnad mellan yrken och professioner utan att vissa yrkesgrupper hade lyckats framställa sitt arbete i en sådan dager att de erhållit ett yrkesmandat för ensamrätt att utföra uppgiften. Yrkenas inbördes förhållanden skapas genom växelverkan och förhandlingar, vilka utförs på mikro- och makroplan och bildar det sociala dramat i arbetslivet (eng. social drama of work). Detta interaktionistiska och socialkonstruktionistiska perspektiv på arbetets karaktär påverkade Hughes studenter, bl.a. Erving Goffman och Eliot Freidson.

Freidsons betydelse för den senare professionssociologins utveckling förbises ofta av dagens professionsforskare eftersom få idag läser den moderna klassikern "Profession of Medicine" (Freidson 1970). Freidsons senare inlägg i debatten om läkarprofessionens utveckling kom dessutom huvudsakligen att ha inflytande på den amerikanska forskningen (Timmermans \& Oh 2010). I den debatt som fördes i mitten på 1980-talet om den amerikanska läkarprofessionens försvagade ställning lanserades två tolkningar: en hypotes om läkarprofessionens avprofessionalisering
(Haug 1975) och en om läkarkårens proletarisering (McKinlay \& Archer 1985). Den förstnämnda hypotesen förutspådde att informationssamhället gav patienter och olika hälsovårdsyrken möjligheter att via tidskrifter och internet få den medicinska kunskap som de behövde och därigenom skulle läkarnas kunskapsmonopol och maktställning brytas i framtiden. Den andra tolkningen förutspådde en tilltagande byråkratisering av hälsovården och att läkarna därigenom skulle bli anställda lönearbetare inom stora hälsovårdsorganisationer och läkarkåren skulle upphöra att vara en autonom profession. Freidson (1984, 1985) kritiserade båda tolkningarna men medgav att den amerikanska läkarkårens ställning höll på att förändras, dvs. den var inte längre den fria och maktfullkomliga grupp som den tidigare varit, men han förutsåg att dess maktställning skulle förbli oförändrad.

Freidson lanserade under årens lopp två egna tolkningar kring detta tema. Den ena var hypotesen om en befäst stratifiering (restratification hypothesis) och den andra var hypotesen om betydelsen av den "tredje logiken". Hypotesen om en befäst stratifiering hävdade att läkarkåren hade anpassat sig till den förändrade situationen genom att skapa en ny inre stratifiering bestående av tre grupper av läkare: ett administrativt ledarskap, en kunskapselit och de praktiserande läkarna. Kunskapseliten utgörs av ett nytt akademiskt skikt av läkare som genererar ny medicinsk kunskap, och denna kunskapsproduktion har gett upphov till nya specialiteter och subspecialiteter. Både den administrativa och kunskapseliten värnar om läkarkårens kunskapsmonopol 
och därmed antas de praktiserande läkarnas professionella dominans inom hälsovården fortsätta. I en senare tolkning om "den tredje logiken" försvarade Freidson den ansats som han i början av sin karriär kritiserat: Talcott Parsons normativa teori. I boken "Professionalism: The Third Logic" lyfter Freidson (2001) fram de tre logiker som påverkar relationen till klienterna: marknad, byråkrati och professionalism. Styrkeförhållandet mellan dessa tre "logiker" påverkar enligt Freidson hälsovårdstjänsternas karaktär och kvalitet. Freidson propagerar för bibehållandet av den kollegiala kvalitetskontroll som professionerna representerar och den yrkesprofessionalism, som han ansåg garanterade att tjänsternas kvalitet skulle tryggas i ett samhälle där marknaden och stora organisationer alltmer hotar professionernas ställning.

En del forskare har ställt sig frågande till Freidsons tvärvändning $\mathrm{i}$ tolkningen av läkarprofessionens särdrag, från hans ursprungliga syn på läkarkåren som en cynisk vinstmaximerare till en syn på läkarkåren som en altruistisk garant för hälsovårdstjänsternas kvalitet. Andra har (t.ex. Dingwall 2006) antytt att Freidson egentligen förebådade det konservativa politiska klimatet i det amerikanska samhället och dess följd i form av både marknadens och de politiska institutionernas bristande förmåga att värna om hälsovårdens kvalitet.

Den brittiska professionsforskningen utvecklades i samma banor på 1970-talet som den av Freidson inspirerade konfliktoch makttolkningen. Terence Johnson (1972) presenterade liknande tankegångar som Eliot Freidson men hans tolkning hade en förankring i den europeiska traditionen som betonade ekonomisk makt, klasser och statens roll. Johnson hade en stor betydelse för den brittiska professionsforskningens utveckling men hans teoretiska bidrag nådde aldrig den amerikanska forskningen.

Freidsons ursprungliga konfliktperspektiv på förklaringen till läkarprofessionens ställning inspirerade andra till nya tolkningar kring temat. Det nyweberianska perspektivet, som uppkom i mitten på 1970-talet, kom att sätta sin prägel på professionsforskningen för tjugo år framåt. En ledande representant för detta perspektiv var Magali Sarfatti Larson vars bok "The Rise of Professionalism" (1977) blev den mest synliga referensen till detta perspektiv. Larson granskade mer i detalj det som Freidson med grov pensel hade skisserat. Hon identifierade de strukturella mekanismer genom vilka en blivande professions kunskapsmonopol skapas och hur både staten och den kapitalistiska ekonomin stöder professionens maktposition. Larson hade sina personliga rötter $i$ den europeiska kulturmiljön men hon var professionellt förankrad i det amerikanska akademiska systemet. Larsons egen syn på professioner lånade element från den amerikanska interaktionistiska synen på arbete och från den europeiska sociologiska traditionen, som tolkar ekonomiska och sociala makrostrukturer i Weberianska och marxistiska termer. Hon erkände relevansen i de teoretiska argument som framförts av både Weber och Freidson. Larson visade liksom Freidson hur förvetenskapligandet av kunskapen och den vetenskapliga kunskapens förankring i universitetssystemet, banade väg för professionaliseringen av yrkesgrupper och för skapandet av ett framgångsrikt 
"professionellt projekt". Termen professionellt projekt har en koppling till Webers syn på marknadens roll och hur sociala grupper strävar efter status och makt. Att skapa en marknad för sin kunskap och tjänster krävde också ett behov av att kontrollera denna marknad.

Den nyweberianska ansatsen kom att ha en starkare förankring i den europeiska professionssociologiska forskningen än den amerikanska. De europeiska sociologerna började kartlägga den historiska process som förklarade olika yrkesgruppers professionella projekt och hur de hade uppnått sin ledande professionella ställning. I denna forskning fick läkarkåren utgöra ett modellexempel och indikator på hur samhällsförändringar påverkade professionernas makt. Samtidigt identifierade forskningen semiprofessionella hälsovårdsyrken som inte helt lyckats i sin professionaliseringsprocess, typ sjuksköterskor och barnmorskor.

I början på 1990-talet gjordes en internationell kartläggning av läkaryrkets utveckling och framtid. Syftet var att identifiera en universell strukturell mekanism i utvecklingen och att bekräfta någon av de existerande hypoteserna inom den professionssociologiska teoretiska debatten (Hafferty \& McKinlay 1993). Projektets amerikanska ledare blev tvungna att konstatera att "There is not one profession of medicine undergoing some universal process of professional dominance or proletarianization" (Hafferty \& McKinlay 1993: 226). I stället fann de att man kan identifiera olika exempel på pågående professionell tillväxt, professionell dominans och professionell nedgång och dessa processer formas av specifika politiska, ekonomiska och kulturella faktorer i en given nationell kontext. Ett liknande europeiskt försök, med fokus på statens roll i de europeiska hälsovårdssystemen, utmynnade $i$ en omfattande kartläggning av läget $i$ olika länder men slutrapporten nådde inte heller fram till resultat som skulle ha bekräftat en överbyggande teoretisk modell kring temat (Johnson m.fl. 1995).

Professionssociologin var redo för en ny teoretisk modell kring temat aktörer och strukturer och luckan fylldes av den amerikanska (och vid Chicago universitetet verksamma) sociologen Andrew Abbotts (1988) systemteori om professioner. Modellen bygger på samma sätt som Larsons teoretiska modell i ett försök att sammanlänka den interaktionistiska och Weberianska traditionen. Abbotts centrala begrepp är jurisdiktion och anspråk (eng. claim) som en typ av gränsdragningsmekanism. Abbott anser att yrkesgrupper och professioner är i en ständig konflikt som går ut på att befästa eller expandera en domän. Arbetsfördelningen mellan olika expertyrken anser Abbott vara präglade av en ständig kamp för bibehållandet eller erövrandet av en viss jurisdiktion, som ger en yrkesgrupp rätten till yrkesutövningen på ett visst område. I den empiriska prövningen av sin systemteori använde sig Abbott av tre olika yrkesgrupper: informationsbaserade yrken (typ bibliotekarier), jurister, och terapeuter.

Senare forskare (t.ex. Witz 1992) har utvecklat Abbotts tema kring jurisdiktion för att peka på de uteslutningsmekanismer (eng. social closure), som en ledande profession kan utöva för att behålla sin marknadskontroll. Andra som varit inspirerade av Freidson och Larson har använt begrep- 
pet skyddad marknad (eng. market shelter), som ungefär motsvarar Abbotts term jurisdiktion. Begreppet skyddad marknad har tillämpats i forskningen om hälsovårdsprofessioner (Timmermans 2008) och tolkningen antyder ett maktperspektiv på professionernas ställning.

Det poststrukturalistiska perspektivet började tillämpas i sociologiska studier om hälsoprofessioner fr.o.m. mitten av 1990-talet. Den syn på makt och social kontroll som till exempel karakteriserar Michel Foucaults synsätt har appellerat mer till europeiska än amerikanska sociologer. Foucaults koppling mellan statens roll, disciplinering och den sociala kontroll som finns inbyggd i kunskap och makt utgör ett analytiskt verktyg för att förstå t.ex. biomedicinens utveckling i de europeiska hälsovårdssystemen (Powell 2011). För de amerikanska sociologerna var förklaringen av de fria professionerna och deras ställning mellan staten och marknaden i fokus för forskningen och teoribyggandet.

Både professionssociologin och det Foucaultska perspektivet delar intresset för läkarprofessionens ställning och biomedicinen som vetenskap och maktmedel i kontrollen av samhället. För professionssociologerna är den renodlade Foucaultska ansatsen fokuserad på förklaringen av andra aspekter än de som varit väsentliga inom professionssociologin. För det första är det diskurserna och deras användning som maktmedel som är i fokus i det Foucaultska synsättet, inte yrkesgrupperna i sig som aktörer eller strukturer. De senare har stått i fokus för professionssociologernas analyser. För det andra är professionernas ställning för sociologerna relaterad till professionernas kunskapsbas och denna kunskap tar sociologerna ofta som given. Foucaults teoretiska bidrag har varit att ifrågasätta den professionella kunskapen och spåra tillbaka hur kunskapen har konstruerats (Goldstein 1984: 177). För Foucault är läkarkåren inte i sig intressant utan snarare hur den "kliniska blicken" skapar kroppen som ett kunskapsobjekt och hur denna kliniska blick verkar som ett maktmedel vilken möjliggör en ny form av disciplinering och reglering av kroppen. Biomedicinen anses både som kunskap och praktik vara en ny form av maktutövning. För Foucault är makten kopplad till staten och dess byråkratiska makt och här finns en anknytning till Max Webers syn på rationalitet och byråkratisk organisation. Foucault är i motsats till Weber inte intresserad av rationalitet i sig, utan av att analysera specifika rationaliteter och praktiker (Power 2011: 42).

Den brittiske sociologen Nikolas Rose (2007) har utvecklat Foucaults tolkning av biomedicinens utveckling till att gälla för de nya inriktningar inom biomedicinen, t.ex. neurovetenskapen och genforskningen, och hur dessa nya inriktningar utövar en ny form av biomakt. Även om Rose granskar olika professioner, behandlar han dem, i likhet med Foucault, inte som aktörer utan som bärare av kunskap och som utövare av en viss praktik som reglerar samhället på ett nytt och dolt sätt.

Inom hälsosociologisk forskning har läkarkårens makt och kunskap varit ett tema som under de senaste tjugo åren utmynnat i specifika hypoteser och teoretiska perspektiv, t.ex. medikaliseringshypotesen, kroppssociologin, aktörnätverk- 
teorin och deras respektive sociologiska företrädare Peter Conrad, Chris Shilling, och Bruno Latour. I dessa diskussioner har man visat hur läkarprofessionen och dess makt är en del av ett större socialt kontrollsystem och hur dessa "regimer" påverkar läkarnas arbete.

Peter Conrads medikaliseringshypotes representerar ett socialkonstruktionistiskt perspektiv på hur läkarprofessionen utövar social kontroll och makt. Conrad anser att sociologernas uppgift är att identifiera vem som har makten att definiera de rådande medicinska och sociala kategorierna, dvs. att rangordna kategorier enligt vissa normativa kriterier. Den tidiga medikaliseringshypotesen gav all denna makt till läkarna, medan Conrad (2005) senare har identifierat nya aktörer som påverkar definitionen av det normala, det patologiska och det som biomedicinen skall behandla. Conrad anser att patientgrupper och läkemedelsindustrin idag innehar en allt större roll i medikaliseringsprocessen. Patientgrupper strävar efter dels att avmedikalisera vissa sjukdomskategorier (t.ex. homosexualitet), dels att medikalisera vissa symptom (som läkarkåren har ansett inte har organisk grund) genom att kräva att de skall ingå $\mathrm{i}$ den officiella sjukdomsklassificeringen (typ fibromyalgi och elöverkänslighet). Läkemedelsindustrins roll i skapandet av nya medicinska diagnoser och behandlingsmetoder har lyfts fram av forskare som kallat den här formen av medikalisering för "farmakologisering" (eng., pharmaceuticalization) (Abraham 2010; Williams m.fl. 2011). Begreppet betonar de globala och ekonomiska processer som har gjort att läkarnas diagnoser och behandlingsmetoder anses idag vara styrda av globala läkemedelskoncerner. Denna tolkning utmanar läkarnas autonoma ställning och deras egen kunskapsbaserade expertis. För det första ifrågasätter man kunskapen som en oberoende produkt av vetenskapliga framsteg inom klinisk forskning. För det andra lyfter man fram att läkemedelsindustrin har skapat närmast godtyckliga sjukdomskategorier enbart för att påverka sin marknadsandel inom den allt mer konkurrensbetonade globala läkemedelsmarknaden. För det tredje påvisar man att läkemedel används av konsumenterna för andra än rent medicinska grunder, dvs. som tekniker för att förbättra den egna kroppens prestationer, t.ex. Prozac och Viagra.

\section{Ett genusperspektiv på hälsoprofessioner}

De tidiga teoretiska perspektiven på och studierna om läkarprofessionen karakteriserades av en könsneutral syn. För Parsons del var det inte frågan om en försummelse utan en följd av hans definition av professionalism, dvs. att kön, ras och etnicitet inte skall påverka karaktären i växelverkan mellan patient och läkare. Parsons teori var normativ, dvs. den var riktgivande men stödde sig inte på empirisk kunskap om läkarnas beteende. De tidigaste empiriska studierna i slutet på 1950-talet (Merton m.fl. 1957, Becker m.fl. 1961) strävade efter att belysa Parsons syn på hur medicinestuderande internaliserar de professionella normerna och beteendena. Dessa två studier inkluderade inte kvinnliga studerande. I dessa fall var förbiseendet av genus 
mer en följd av forskarnas egen syn på kvinnornas roll i arbetslivet och det metodval som de därigenom fattade än av en skev tolkning av den Parsonska synen på läkarprofessionen.

Trots att Freidson kritiserade olika brister i det funktionalistiska perspektivet på läkarprofessionens ställning, nämnde han inte dess könsneutrala perspektiv. I stället fortsatte han att reproducera det könsneutrala synsättet i sin tolkning av läkarprofessionens makt och praktik. Genusperspektivet saknades i alla Freidsons arbeten trots att han i början av 1970-talet samarbetade med ledande feministiska forskare (t.ex. Freidson och Lorber 1972).

Genusperspektivet lanserades i mitten av 1970-talet då feministiska hälsoaktivister började granska hur hälsovården bemötte kvinnornas hälsovårdsbehov. Den radikala feministiska kritiken identifierade läkarkåren som en del av patriarkatet och hälsovården som en kontroll av kvinnokroppen och som en del av kvinnans underordning i samhället. Barbara Ehrenreichs verk (Ehrenreich \& English 1973, 1978) och Ann Oakleys (1984) kritik av gynekologins praktiker utgjorde två klassiker som påverkade den senare amerikanska respektive brittiska genusteoretiska forskningen om professioner och kvinnor som patienter i hälsovården.

Det var först genom uppkomsten av den nyweberianska ansatsen i professionssociologin som den sociologiska forskningen började granska hälsovårdsyrken ur ett genusperspektiv. Studier rapporterade hur läkarprofessionen i olika länder hade blivit ett manligt yrke då den medicinska kunskapen förvetenskapligades (Ehrenreich \&
English 1973, Witz 1992). Ann Witz (1992) identifierade olika uteslutnings- och inneslutningstrategier som påverkat representationen av kvinnor inom olika hälsovårdsyrken. Hon visade att männen har använt uteslutningsstrategier för att skapa kollektiva (manliga) kompetenskriterier som uteslutit kvinnor från vissa yrken och professioner. Inneslutningsstrategin innebär att man har försökt stärka kvinnornas ställning inom professioner genom att betona individuella kompetenskriterier. Witz pekar också på kontrollmekanismer mellan yrken som använder sig av könsbundna demarkationsstrategier så att kvinnor definieras som lämpliga inom vissa yrkesområden men samtidigt underordnas de av mansdominerade professioner. Ett exempel är (de tidigare mansdominerade) läkarnas makt över barnmorskorna som yrkesgrupp. Sjuksköterskorna har använt sig av duala strategier i sitt professionaliseringsprojekt, vilket har inneburit att omsorgsarbetets värde uppvärderats gentemot läkarprofessionen samtidigt som nya kvalifikationskrav uteslutit andra kvinnliga yrkesgrupper, t.ex. närvårdare. Indelningen av yrken inom hälsovården har tidigare präglats av en mansdominerad överordnad profession och olika kvinnodominerade underordnade semiprofessioner.

Den tilltagande andelen kvinnor inom läkaryrket har använts som ett analytiskt verktyg för att förstå de strukturella förändringar som pågår inom läkaryrket och vilken roll kvinnorna i framtiden har i hälsovården. Här har termen feminiseringen av läkaryrket använts för att peka på kommande förändringar. Termen feminiseringen av läkaryrket har använts både 
i positiv och negativ mening. Den positiva innebörden har betonats av dem som har sett den ökade andelen kvinnor i läkaryrket som en jämställdhetsfråga.

För det första utvisar statistiken i de flesta västländer en ökande andel kvinnliga läkare inom hälsovården. År 2009 utgjorde kvinnorna 50-60 procent av läkarna i Polen, Tjeckiska republiken, Ungern, Portugal, Slovenien, Slovakien och Finland; mellan 40-47 procent i Österrike, Frankrike, Tyskland, Israel, Nya Zealand, Norge, Sverige och Storbritannien; och omkring en tredjedel i Belgien, Kanada, Italien, Turkiet, Schweiz och USA (se Tabell 1). För det andra har den internationella forskningen visat att det existerar en könssegregering i specialiseringen inom läkarprofessionen och att trenden fortsatt trots en ökad andel kvinnor inom läkarkåren som helhet. De kvinnliga och manliga läkarna tenderar att verka inom specialiteter som reproducerar den traditionella arbetsfördelningen mellan könen. I de flesta länder finner man t.ex. att pediatrik är ett kvinnodominerat område medan kirurgi är ett utpräglat mansdominerat område. Trenden bekräftas av de nordiska länderna som sedan början på 1970-talet har haft en hög andel kvinnor inom läkarkåren. Tabell 2 visar att barn och ungdomspsykiatri och geriatrik är kvinnodominerade specialiteter medan kirurgi är ett mansdominerat område. Reproduktion och sexualitet är specialiteter som är uppdelade enligt kön: Gynekologi och obstetrik var tidigare ett tämligen mansdominerat område men är idag i de flesta västländer ett kvinnodominerat område, medan urologi är ett mansdominerat område, så även i de nordiska länderna (se Tabell 2).
De kvinnliga läkarnas fördelning inom vissa specialiteter och relativa frånvaro från

\section{Tabell I.}

Kvinnor i läkarkåren i olika OECD länder år 2009.

\begin{tabular}{|c|c|}
\hline Region & $\begin{array}{c}\text { Kvinnor }(\%) \\
\text { av totala } \\
\text { antalet } \\
\text { läkare }\end{array}$ \\
\hline \multicolumn{2}{|c|}{ Post-Sovjetiska länder } \\
\hline Estland & 74 \\
\hline Polen & 56 \\
\hline Slovakiska republiken & 55 \\
\hline Slovenien & 59 \\
\hline Tjeckiska republiken & 53 \\
\hline Ungern & 52 \\
\hline \multicolumn{2}{|c|}{ Norden } \\
\hline Danmark & 45 \\
\hline Finland & 56 \\
\hline Island & 32 \\
\hline Norge & 42 \\
\hline Sverige & 46 \\
\hline \multicolumn{2}{|c|}{ Central och Syd-Europa } \\
\hline Belgien & 35 \\
\hline Italien & 37 \\
\hline Frankrike & 40 \\
\hline Irland & 38 \\
\hline Portugal & 49 \\
\hline Spanien & 47 \\
\hline Storbritannien & 43 \\
\hline Schweiz & 35 \\
\hline Turkiet & 37 \\
\hline Tyskland & 41 \\
\hline Österrike & 44 \\
\hline \multicolumn{2}{|c|}{ Icke- Europeiska länder } \\
\hline Canada & 38 \\
\hline Nya Zealand & 40 \\
\hline Förenta staterna & 31 \\
\hline
\end{tabular}

Källa: OECD Health Data 2011; Nordic Medical Associations 2010. 
ledarpositioner i sjukhusens administration och inom akademisk medicin, har sociologerna ansett ge belägg för hur inbyggda manliga värderingar och strukturer påverkar kvinnliga läkares karriärer. Amerikanska och brittiska forskare har identifierat de kulturella och strukturella hinder som fortsätter att påverka kvinnors karriärer i läkaryrket, t.ex. diskriminering och brist på handledare (se t.ex. Walsh 1977, More 1999, Lorber 1984, Boulis \& Jacobs 2008).

Ett flertal sociologiska studier har granskat kvinnornas ställning i läkarkåren i de nordiska länderna och orsaken till de könsrelaterade karriärvalen. Elisabeth Gjerberg (2002) har dokumenterat en könssegregering inom läkarprofessionen i Norge och pekat på olika strukturella mekanismer som befäster könsrelaterade karriärval. Gerd Lindgren (1997), Torgerdur Einarsdottir (1997) och Kristina Eriksson (2003) har studerat den svenska läkarprofessionen och visat att dolda könsmättade struktu- rer befäster de manliga värderingarna och praktikerna i läkarkåren och gör det svårt för kvinnliga läkare att verka på andra än manliga villkor. Lindgrens, Erikssons, Einarsdottirs och Gjerbergs resultat kunde också bekräftas i Riskas (2001) jämförande studie om kvinnornas ställning i läkarkåren och i olika specialiteter i de nordiska länderna, i Förenta staterna och i Ryssland.

Den strukturella tolkningen av de kvinnliga läkarnas ställning och karriärval har dominerat i den nordiska professionsforskningen. Däremot har socialisationsteorin varit väl representerad i brittiska studier (t.ex. Elston 2009). En nyare version av teorin, som går under benämningen preferensteorin (Hakim 2000), har använts för att förklara varför kvinnor gör karriärval som befäster deras traditionella ställning $\mathrm{i}$ familjen och arbetslivet. Enligt preferensteorin fattar kvinnor sina karriärval på basen av deras strävan efter en balans mellan de krav som ställs på dem i familje- och arbets-

\section{Tabell 2.}

Kvinnliga läkare (\%) i valda specialiteter i Finland, Sverige och Norge, 2011.

\begin{tabular}{l|c|c|c}
\hline Specialitet & Finland & Sverige & Norge \\
\hline Allmänmedicin & 58 & 46 & 32 \\
\hline Anestesi & 47 & 33 & 27 \\
\hline Internmedicin & 44 & 36 & 26 \\
\hline Barn \& ungdomsmedicin & 66 & 53 & 44 \\
\hline Barn \& ungdomspsykiatri & 89 & 68 & 70 \\
\hline Geriatrik & 70 & 63 & 42 \\
Kirurgi & 21 & 20 & 14 \\
\hline Patologi & 42 & 45 & 48 \\
\hline Psykiatri & 61 & 53 & 45 \\
\hline Obstetrik \& gynekologi & 75 & 66 & 58 \\
Urologi & 18 & 15 & 16 \\
\hline Kvinnor\% av totala antalet läkare & 57 & 48 & 43 \\
\hline
\end{tabular}

Källa: FLF 2011, SLF 2011, NLF 2011.

Elianne Riska: Hälsoprofessioner: Teoretiska perspektiv och forskningstrender. 
livet under olika livsfaser (Hakim 2000: 276).

I den amerikanska och brittiska forskningen har termen feminiseringen av läkaryrket inte enbart getts en positiv utan också en negativ innebörd. Man har förknippat den ökade andelen kvinnor med en framtida minskad status och makt för läkarprofessionen. Kritikerna har inte kunnat bekräfta att detta skulle ha skett (se Boulis \& Jacobs 2008).

En speciell nisch inom professionsstudier på hälsovårdens område utgör barnmorskeyrket. I motsats till sjuksköterskeyrket, som nästan uteslutande har granskats av sin egen yrkeskår inom ramen för disciplinen "nursing science", har barnmorskeyrket undersökts huvudsakligen av sociologer. De sociologiska studierna av barnmorskeyrket karakteriseras av en historisk och jämförande ansats (t.ex. De Vries m.fl. 2001). Här kan nämnas ett par nordiska klassiker som analyserat hur barnmorskeyrkets karaktär ändrades genom uppkomsten av ett modernt hälsovårdssystem: Lise Kjølrøds (1992) undersökning om det norska barnmorskeyrket och Sirpa Wredes (2001) studie om det finländska barnmorskeyrket.

\section{Slutsatser}

Denna artikel har skisserat och analyserat de viktigaste teoretiska perspektiven inom professionssociologin: det funktionalistiska, interaktionistiska, och nyweberianska perspektivet samt systemteorin och det poststrukturalistiska perspektivet. Jag har gett en kronologisk redogörelse för de fem perspektiven och översikten har lyft fram tre kännetecken för forskningen om hälsoprofessioner. För det första har professionssociologin präglats av en förvånansvärt omfattande konsensus under olika epoker av forskningsfältets historia $\mathrm{i}$ jämförelse med de flesta av sociologins delområden. Jag har betonat den dominans som ett teoretiskt perspektiv har haft i forskningen under den femtio år långa beaktade perioden. Forskning om hälsoprofessioner präglas idag av en mer eklektisk hållning till de olika teoretiska perspektiven än tidigare. Professionssociologin följer därmed utvecklingen inom andra delområden i sociologin som karakteriserats av en ökad fragmentering. Andra discipliner, såsom organisationsstudier och arbetsmarknadsforskning, har annekterat sociologins centrala begrepp och använt dessa för att utreda sociala förändringar inom arbetslivet, inklusive professionernas ställning (Halford \& Strangleman 2009). Denna trend är speciellt kännetecknande för studier som tangerar genusforskning om professioner där organisationssociologin till en stor del har tagit över forskningen om genus, utbildning och ledarskap (se t.ex. Jeanes m.fl. 2011).

För det andra har jag visat att läkarprofessionen har utgjort en proto- eller idealtyp på en modern profession i teoribildningen om professioner. Sociologer har betonat läkarprofessionens specifika kunskapsbaserade och etikrelaterade egenskaper vis a vis andra yrkesgrupper. Fokuseringen på läkarkåren har gjort att sociologerna har försummat att dokumentera och analysera olika utvecklingsfaser i professionaliseringen av andra hälsoyrken. Fortfarande utförs studier av sjuksköterskeyrket huvudsakligen av yrkesgruppen själv inom 
ramen för disciplinen "nursing science". Den psykologiska ansats som ofta tillämpas inom den senare forskningen har lett till att de professionssociologiska aspekterna i yrkesgruppens utveckling och arbetets karaktär har försummats.

För det tredje har jag redovisat den kritik som framförts mot den könsneutralitet som präglat de dominerande teoretiska perspektiven inom professionsforskningen. Genusperspektivet i professionsforskningen har lyft fram kvinnornas underordnade roll i hälsovården och visat att kvinnorna i form av läkare inom vissa specialiteter, barnmorskor och sjuksköterskor har delegerats denna yrkesroll på grund av kulturella och strukturella orsaker. Det finns de amerikanska och brittiska kvinnoforskare som har ansett att hälsovårdens kvalitet kommer att förbättras då de kvinnliga läkarna i framtiden utgör majoriteten av läkarprofessionen. Detta synsätt förknippar de kvinnliga egenskaperna (empati, patientorientering) med "good doctoring", ett essentialistiskt synsätt som utmanar den sakorienterade professionalism som Talcott Parsons förespråkade. Forskning har visserligen visat att kvinnliga läkare är mer empatiska, men de skiljer sig däremot inte i sina diagnosbeslut och behandlingsmetoder från sina manliga kolleger (Kilminster m.fl. 2007).

Det finns vissa centrala frågor och utmaningar som forskningen om hälsoprofessioner idag borde lyfta fram. Julia Evetts, en central gestalt inom den europeiska professionsforskningen, har aktivt försökt påverka debatten om teoribildningen inom professionsforskningen (se t.ex. Evetts 2006, 2008, 2011). Hon har bl.a. påpekat hur professionsforskningen främst analy- serat professioner inom ett lands gränser och inte uppmärksammat hur professioner idag agerar globalt inom ramen för sina egna internationella organisationer (Evetts 2008). EU-politiken med sina olika direktiv är ett exempel på en ny typ av styrning av kunskapsbaserade professioner (McKinlay \& Marceau 2008). Inom hälsovården är den nya evidensbaserade medicinen ett annat exempel på en kombination av extern och intern styrning (Timmermans \& Oh 2010, Liljegren \& Parding 2010, Evetts 2011). Även om denna typ av styrning kan tänkas öka den offentliga sektorns kontroll över professionernas arbete, agerar professionerna både på makro- och mikronivå för att återfå sin kontroll. Evetts (2011) har visat att olika internationella intresseorganisationer på global nivå är involverade i att påverka de internationella och nationella direktiven. På mikronivå kan man iaktta hur olika yrkesgrupper använder begreppet professionalism i sin verksamhet $i$ avsikt att få sina medlemmar att internalisera professionella värderingar och därigenom skapa en ökad självreglering bland yrkesgruppens medlemmar (Fournier 1999).

Globaliseringen har väckt ett intresse för hur olika yrkesgrupper rör sig på den internationella arbetsmarknaden och framför allt hur den offentliga och privata sektorns hälsovård behöver tillskott från den globala arbetsmarknaden för att möta de nationella behoven av arbetskraft. Att detta är en kvinnofråga har påpekats av ett flertal forskare (t.ex. Ehrenreich \& Hochschild 2004) och termen "global care chain" har lanserats för att peka på de komplexa nätverk som formar utbudet och efterfrågan på hälsovårdsprofessioner. Trenden har 
dokumenterats för de nordiska ländernas del (Isaksen 2010), och sjuksköterskeyrkets allt mer globala profil har påvisats (Wrede
2010). Det globala forskningsfältet ställer nya teoretiska utmaningar för professionsforskningen.

\section{Referenser}

Abbott, A. (1988). The System of Professions: An Essay on the Division of Expert Labor. Chicago: University of Chicago Press.

Abraham, J. (2010). Pharmaceuticalization of society in context: Theoretical, empirical and health dimensions. Sociology, 44(4), s. 603-622.

Becker, H. S., B. Geer, B., Hughes, E.C. \& Strauss, A.L. (1961). Boys in White: Student Culture in Medical School. Chicago: University of Chicago Press.

Boulis , A.K \& Jacobs, J.A. (2008). The Changing Face of Medicine: Women Doctors and the Evolution of Health Care in America. Ithaca: Cornell University Press.

Conrad, P. (2005). The shifting engines of medicalization. Journal of Health and Social Behavior, 46(1), s. 3-14.

DeVries, R., Benoit, C., van Teijlingen, E.R. \& Wrede, S., red. (2001). Birth by Design: Pregnancy, Maternity Care and Midwifery in North America and Europe. London: Routledge.

Dingwall, R. (2006). The enduring relevance of the professional dominance. Knowledge, Work and Society, 4:(2), s. 77-98.

Ehrenreich, B. \& English, D. (1973). Witches, Midwives and Nurses: A History of Women Healers. Old Westbury: The Feminist Press.

Ehrenreich, B. \& English, D. (1978). For Her Own Good: 150 Years of the Experts' Advice to Women. Garden City, N.Y.: Anchor Press.

Ehrenreich, B. \& Hochschild, A.R. (2004). Global Woman: Nannies, Maids, Sex Workers in the New Economy. New York: Owl Books.

Einarsdottir, T. (1997). Läkaryrket i förändring: En studie av den medicinska professionens heterogenisering och könsdifferentiering. Göteborg: Sociologiska institutionen, Göteborgs universitet.

Elston M.A. (2009). Women and Medicine: The
Future. London: Royal College of Physicians.

Eriksson, K. (2003). Manligt läkarskap, kvinnliga läkare och normala kvinnor. Stehag: Förlags AB Gondolin.

Evetts, J. (2006). The sociology of professional groups: New directions. Current Sociology, 54(1), s. 133-143.

Evetts, J. (2008). Professional work in Europe: Concepts, theories, and methodologies. European Societies, 10(4), s. 525-544.

Evetts, J. (2011). A new professionalism: Challenges and opportunities. Current Sociology, 59(4), s. 406-422.

Evetts, J. , Gadea, C., Sanchez, M. \& Saez, J. (2009). Sociological theories of professions: Conflict, competition, and cooperation. I A. Dennis \& D. Kalekin-Fishman, red., The ISA Handbook in Contemporary Sociology. London: Sage, s. 140154.

Fournier, V. (1999). The appeal to "professionalism" as a disciplinary mechanism. The Sociolo gical Review, 47(2), s. 280-307.

Freidson, E. (1970). Profession of Medicine. New York: Mead and Company.

Freidson, E. (1984). The changing nature of professional control. Annual Review of Sociology, 10, s. $1-20$.

Freidson, E. (1985). The reorganization of the medical profession. Medical Care Review, 42, s. 11-35.

Freidson, E. (2001). Professionalism: The Third Logic. Chicago: University of Chicago Press.

Freidson, E. \& Lorber, J., red. (1972). Medical Men and Their Work: A Sociological Reader. Chicago: Aldine.

Gjerberg, E. (2002). Kvinner i norsk medisin—mot full integrering? Oslo: The Work Research Institute. 
Goldstein, J. (1984). Foucault among the sociologists: The "disciplines" and the history of the professions. History and Theory, 23(2), s. 170192.

Hafferty, F.W. \& McKinlay, J.B., red. (1993). The Changing Medical Profession: An International Perspective. New York: Oxford University Press.

Hakim, C. (2000). Work-Lifestyle Choices in the 21 Century: Preference Theory. Oxford: Oxford University Press.

Halford, S. \& Strangleman, T. (2009). In search of the Sociology of Work: Past, present and future. Sociology, 43, s. 811-828.

Haug, M. (1975). The deprofessionalization of everyone? Sociological Focus, 3, s. 197-213.

Hughes, E. C. (1958). Men and their Work. Glencoe, Ill.: Free Press.

Isaksen, L.E. (2010). Global Care Work: Gender and Migration in Nordic Countries. Lund: Nordic Academic Press.

Jeanes, E., Knights, D. \& Martin, P. (2011). Handbook of Gender, Work and Organization. Chichester: Wiley.

Johnson, T. (1972). Professions and Power. London: Macmillan.

Johnson, T., Larkin, G. \& Saks, M., red. (1995). Health Professions and the State in Europe. London: Routledge.

Kilminster S., Downes, J., Gough, B., MurdochEaton, D. \& Roberts, T. (2007). Women in medicine-is there a problem? A literature review of the changing gender composition, structures and occupational cultures in medicine. Medical Education, 41, s. 39-49.

Kjølsrød, L. (1992). Jordmor der mor bor? En sociologisk studie av jordmoryrket etter 1945. Oslo: Institutt for sosiologi, Universitetet i Oslo.

Larson, M.S. (1977). The Rise of Professionalism. Berkeley: University of California Press.

Liljegren, A. \& Parding, K. (2010). Ändrad styrning av välfärdsprofessioner-exemplet evidensbasering i socialt arbete. Socialvetenskaplig tidskrift, 17(3-4), s. 270-288.

Lindgren, G. (1999). Klass, kön och kirurgi. Malmö: Liber.
Lorber, J. (1984). Women Physicians: Careers, Status, and Power. London: Tavistock.

McKinlay, J.B. \& Arches, J. (1985). Towards the proletarianization of physicians. International Journal of Health Services, 15, s.161-195.

McKinlay, J. B. \& Marceau, L.D. (2008). When there is no doctor: Reasons for the disappearance of primary care physicians in the US during the early 21st Century. Social Science and Medicine, 67, s. 1481-1491.

Merton, R.K, Reader, G.G. \& Kendall, P.L., red. (1957). The Student-Physician: Introductory Studies in the Sociology of Medical Education. Cambridge: Harvard University Press.

More, E.S. (1999). Restoring the Balance: Women Physicians in the Profession of Medicine, 18501995. Cambridge, MA: Harvard University Press.

Oakley, A. (1984) The Captured Womb. Oxford: Blackwell

OECD (2011). OECD Health Data 2011. (www. oecd.org/health/health data, accessed 26.7.2011)

Parsons, T. (1951). The Social System. New York: Free Press.

Power, M. (2011). Foucault and sociology. Annual Review of Sociology, 37, s. 35-56.

Rose, Nikolas (2007). The Politics of Life Itself: Biomedicine, Power, and Subjectivity in the Twentyfirst Century. Princeton: Princeton University Press.

Timmermans, S. (2008). Professions and their work: Do market shelters protect professional interests? Work and Occupations, 35, s. 164188.

Timmermans, S. \& Oh, H. (2010). The continued social transformation of the medical profession. Journal of Health and Social Behavior, 51(Supplement), s. 94-106.

Walsh, M.R. (1977). Doctors Wanted: No Women Need Apply: Sexual Barriers in the Medical Profession, 1835-1975. New Haven: Yale University Press.

Williams, S.J., Martin, P. \& Gabe, J. (2011). The pharmaceuticalisation of society? A framework for analysis. Sociology of Health and Illness,

Elianne Riska: Hälsoprofessioner: Teoretiska perspektiv och forskningstrender. 
33(5), s. 710-725.

Witz, A. (1992). Professions and Patriarchy. London: Routledge.

Wrede, S. (2001). Decentering Care for Mothers:

The Politics of Midwifery and the Design of Finnish Maternity Services. Åbo: Åbo Akademi Press.

Wrede, S. (2010). Nursing: Globalization of a female-gendered profession. I E. Kuhlmann \& E. Annandale, red., The Palgrave Handbook of Gender and Health Care. Houndmills: Palgrave, s. 437-453.

Övriga källor: Läkarfakta broschyrer utgivna av Finlands läkarförbund (FLF), Sveriges läkarförbund (SLF), Den Norske legeforening (NLF).

\section{Summary}

\section{Health professions: Theoretical perspectives and research trends}

This article presents an overview of five major theoretical perspectives on health professions: the functionalist, the interactionist, the neo-Weberian and the post-structuralist perspective and system theory. In these discussions the medical profession has served as a prototype of the power but also of the current challenges to the power of a profession. In early theori- zing on professions, gender was a neglected dimension and only recently has gender been included in the analysis of health professions. In current discussions about globalization and professions, the previous focus on the nation state as the arena for professionalizing projects has shifted to global concerns, including the "global care chains". 